\title{
ASSESSMENT OF INDIA'S FISCAL AND EXTERNAL SECTOR VULNERABILITY: A BALANCE SHEET APPROACH
}

\author{
Krishanu Pradhan*
}

\begin{abstract}
The paper is an attempt to assess India's fiscal and external sector vulnerability in the context of deterioration of major macroeconomic indicators in recent years. Balance Sheet Approach developed mainly by the IMF studies is applied to analyze the episodes of major fiscal, financial and external payment crisis in developing countries since late 1990s to early 2000. The present work assesses the vulnerability in India's fiscal and external sector by descriptive and comparative analyses of relevant indicators, and developing a composite vulnerability index consisting of the indicators under study. If the inability to smooth financeability of public debts, budgetary deficits and external sector financing needs as the indicators of fiscal and external sector vulnerability, India does not face risk of such threat at present and hence signify an absence of overall macroeconomic vulnerability than generally perceived.
\end{abstract}

Key Words: Public debt, Debt Servicing, Fiscal Imbalance, External Indebtedness

JEL Code: E60, F34, H63

\section{Introduction}

A sustained increase in combined Union and State governments' budgetary deficits in the aftermath of recent global financial and fiscal crisis raised questions about fiscal sustainability, solvency of government and efficacy of fiscal policy in restoring macroeconomic stability in India. In the recent past, secular decline in overall growth and investment prospects, persistently high inflation and unprecedented external imbalance have undoubtedly caused concern about macroeconomic stability.

The quantum jump in fiscal deficits to over $8 \%$ of GDP since 2008-09 due to the expansionary fiscal policy to protect the economy from the global financial crisis and the significant slowdown since 2011-12 have raised concern about sovereign rating downgrades and the sustainability of fiscal policy. Besides, the current level of debt/GDP (around 70\%) in India is far higher than the different Finance Commissions' long-term target of debt/GDP (below 60\%) and poses significant risk to macroeconomic stability. A sustained increase in current account deficits (CAD/GDP) from1.27\% during 2008-09 to 4.19\% during $2009-10$ and finally to $6.21 \%$ during first quarter of $2012-13$ has raised concern about India's external sector vulnerability (RBI, 2013). Consequently, the unprecedented increase in India's net external indebtedness from US\$ 67bn in 2009 to US\$ 159bn in 2010 and US\$ 245bn in 2012, and record fall in rupee-dollar exchange rate from Rs.54/US\$ during April, 2013 to Rs.68.8/US\$ on $28^{\text {th }}$ August, 2013, brought back memories of India's external payment crisis in 1991.

The major macroeconomic crisis of 1991 and consequent economic reforms asked for consistent policy efforts for internal and external sector stabilization under structural adjustment

\footnotetext{
* Research Scholar at Institute for Social and Economic Change (ISEC), Bangalore, India. Emailkrishanup@gmail.com,

The present paper is based on the author's ongoing Ph.D work at the "Institute for Social and Economic Change (ISEC)", on the ICSSR Institutional Doctoral Fellowship scheme under the supervision of Prof M R Narayana. Grateful thanks are due to Ms B P Vani for valuable comments and suggestions on an earlier version of this paper. Special thanks to the anonymous referee whose comments and suggestions have been instrumental in revising this article. However, usual disclaimers apply.
} 
program (SAP). The need to eliminate monetization of budgetary deficits and the consequent reliance on market borrowing to finance deficits and debt by government was an important mandate under SAP. Elimination of automatic monetization of deficits since 1997-98 by an agreement between the RBI and the Government of India, and subsequent imposition of fiscal rules (Fiscal Responsibility and Budget Management, i.e. FRBM for Centre and Fiscal Responsibility Legalization, i.e. FRL for State governments) marked the beginning of a new era in the management of fiscal policy in India. The resultant growing reliance on market borrowing has exposed government's balance sheet to the creditors' assessment to determine the creditworthiness of government to finance deficits. Similarly, in external sector, the growing integration of Indian economy to rest of the world in terms of international trade and capital flow in one hand and the unprecedented deterioration in some of the external sector indicators on the other has exposed India's ability to honor external payment obligations.

Pioneering research on assessing macroeconomic vulnerabilities by applying balance sheet approach (BSA) to identify weakness in different macro sectors and their transmission risk to cause crisis can be traced to IMF studies (2002, 2004, 2008, 2011a, 2011b and 2012). Disaggregated balance sheet analysis helps to identify different types of balance sheet risks like currency and maturity mismatch risk, solvency risk, capital structure and hidden contingent liability risk in different macroeconomic sectors. The degree of incidence of these risk factors helps to explain the episodes of fiscal-financial-external payments crisis in a number of developing countries since late 1990s. The IMF studies have further tried to quantify the risk and uncertainty from different macro sectors in the sovereign risk adjusted balance sheet and provide early warnings in this aspect ${ }^{1}$. The concepts, analytical framework and methods like value at risk (VaR), early warning system (ERS), contingent claim analysis (CCA) are applied in this regard. Subsequently, taking cues from the IMF (2002), the study by Reinhart, Rogoff and Savastano (2003) tried to explain why the developing countries historically run into problems at much lower levels of external debt/GDP than developed countries. Literature on 'original $\sin ^{\prime}$ by Eichengreen, Hausman and Panizza (2002 and 2003) highlighted the importance of currency mismatch and inability to borrow at local currency with longer maturity in explaining the difference between the debt structure of developing and developed countries. Yeyati and Sturzenegger (2007) proposed a methodology to assess the fiscal sustainability of two Latin American countries - Argentina and Chile based on balance sheet definition of the respective country's net worth and its distribution as a function of changing macroeconomic environment. Recent studies like Bachellerie and Couillault

1 Assessment of macro crisis, including episodes of fiscal, financial and exchange rate or BoP crisis is extremely complex and cumbersome to derive a robust and realistic solution or early warnings to the policy makers in advance. It is due to the multiplicity of approaches, analytical frameworks, theoretical and functional relationships among the inter-connected variables and sophistication of statistical techniques and tests and the way one defines crisis events. In this context, Wyplosz (2007) noted that fiscal sustainability or external vulnerability analysis is essential for good macroeconomic policies, but its definition and assessment is even more challenging and the assessment is valid only within the bounds of underlying assumptions. Added complexity does not always improve assessments. The IMF (2011b) study adopted fiscal vulnerability index (FVI) and fiscal stress index (FSI) to an effective monitoring system, providing early warning of extreme "tail events" like debt default, exchange rate crisis, financial crisis etc. However, both indices have their usual shortcomings. The present paper uses the FVI to say whether external vulnerability in recent times is close to the severe external crisis faced in 1991 or the fiscal vulnerabilities are close to their reference period vulnerabilities. The FSI depends on the specific definition of "credit event" or crisis, and is highly sensitive to the way one defines the fiscal or external crisis. Considering the simplicity and scope of the present study, such an exercise is left out and constitutes one limitation of this study. However, grateful thanks are due to the referee for his suggestion to consider a 'dynamic framework' to generate early warnings based on the FSI. 
(2005), and Poeck and Wijffelaars (2012) have explored the role of currency and maturity mismatch in debt structure, capital structure mismatch, assets-liability mismatch causing weakness in banking and financial sectors, external imbalance with high $C A D$ and its financing with short-term debt flow, to explain the episodes of fiscal-financial and external payment crisis in East Asian, Latin American and recent Euro zone countries.

In Indian context, the balance sheet approach (BSA) to macroeconomic vulnerability received only limited attention of researcher except Ruobini and Hemming (2004). Their study addressed different aspects of balance sheet vulnerability and drew a grim picture of India's macroeconomic vulnerability mainly because of unsustainably high fiscal deficits, revenue deficits, primary deficits and public debt as share of GDP, heavy concentration of bank assets in government debt and its consequent financial repression causing fragile banking system, etc. However, the major departure of present study is a more specific focus to assessing the fiscal and external sector vulnerabilities rather than assessing the entire macroeconomic sectors like banking and financial sector vulnerability or vulnerability arising out of policy credibility and political instability, as was done by Roubini and Hemming (2004) for India. Moreover, in-depth and broad- based detailed analysis of several indicators of fiscal and external sector remain as the prime focus of the study. This departure is mainly in view of the sustained deterioration in fiscal health and external imbalance in recent years, and its impact on overall macroeconomic vulnerability. In addition, in a developing country context, often a fiscal crisis gets rapidly transmitted into external sector crisis and vice-versa, as experienced in the East Asian crisis in the late 1990s.

In light of the above, the key research question in the Indian context is how to assess the financeability and vulnerability of fiscal and external sectors by applying BSA and its implication to India's macroeconomic vulnerability.

The rest of the paper is organized as following: Section 2 provides a brief look at the origin of BSA in the context of rethinking and re-genesis of fiscal, financial and external payment crisis; Section 3 offers methodology of analyzing and applying BSA to assess India's fiscal and external sector vulnerability. Section 4 depicts variable description, measurement and data sources for construction of balance sheet indicators while Section 5 is devoted to results by assessing vulnerability under broadly classified under three categories of indicators - debt-servicing burden, fiscal imbalance, external sector indicators, and with a composite vulnerability index (CVI) consisting of indicators of these categories separately. Section 5 also incorporates some of the distinctly favorable factors prevailing in India's fiscal structures. The major conclusions and implications are listed in section 6.

\section{What is Balance Sheet Approach (BSA)?}

The origin of BSA emerged from the rethinking, re-genesis and resolution of currency, fiscal and financial crisis in East Asian and Latin American countries since mid of 1990s to early 2000s. The IMF study (2004) defined BSA as an analytical framework that makes it possible to identify the balance sheet vulnerabilities and imbalances in different economic sectors. It integrates stock side and flow side imbalance to explore weakness in different sectors of the economy. The approach helps to indentify the risk of financeability or repayment obligations and financing gaps in different macro sectors and their possible transmission risk to cause crisis. Due to growing importance of BSA to financial and currency 
crisis, its applicability to assess a country's macroeconomic vulnerability gained importance in studies by IMF (2002, 2004, 2008, 2011a and 2012), Roubini and Hemming (2004), Bachellerie and Couillault (2005). As per Roubini and Hemming (2004), the balance sheet approach is all about financeability of debt, deficits or aggregate financing gaps to indentify the risk and vulnerability existing in a country's overall macroeconomic structure and their possible transmission risk to cause macro crisis.

\section{Methodology}

The proposed study mainly endeavors to make on descriptive and comparative analysis of relevant indicators and developing a composite vulnerability index (CVI) to address the fiscal and external sector vulnerability in India, on the lines of studies by IMF (2002, 2004 and 2011b) and Roubini and Hemming (2004). However, the indicators used in the present study are not necessarily the same as used by Roubini and Hemming (2004) or IMF studies for the reason that the authors, in a broader framework of explaining different episodes of global fiscal, financial, currency and external payment crisis, have used balance sheet vulnerabilities of financial sector, private corporate sector, household sector, core government sector, public sector undertakings and external sector. The present study covers balance sheet vulnerabilities of both Union and State governments in addition, the external sector. Moreover, the fiscal sector is decomposed in to debt serving burden and fiscal imbalance including stock and flow side. To measure debt-servicing burden, generally the ratio of interest payments to revenue receipts or to GDP is considered in earlier studies. However, the present paper uses five different measure of debt servicing burden. Similarly, to assess fiscal imbalance, some earlier studies have used the fiscal deficits/GDP, revenue deficits/GDP and debt/GDP, and in some cases based on availability of data, the contingent or off budget liabilities. In the present context, the assessment of India's stock and flow side of fiscal imbalance is made based on eight indicators depending upon their relevance and availability of data in Indian context. External vulnerability has been taken into consideration because of its rapid transmission risk and potential to adversely affect the public finance of a country, as had happened in East Asian countries in the latter half of 1990s. Assessment of India's external sector vulnerability is based on a total nine external sector indicators in present context. Thus, various indicators used under the three broadly classified categories are debt servicing burden, fiscal imbalances and external sector.

The reference period for assessment of debt-servicing burden and fiscal imbalance is 1998-99 to 2004-05. The large market borrowing by government due to cessation of monetized deficits since 1997-98 and implementation of fiscal rules mainly by Union government since 2004-05, and its subsequent implementation by most of the State governments justify the selection of such reference period for the study. A comparison of reference period indicators with the recent period indicators helps to understand the change in relative vulnerability of the respective indicators. The reference period for the external sector vulnerability is the years 1990 to 1992, which has been compared with the recent period, i.e. 2008-09 to 2011-12. The external payment crisis during 1990-1992 and recent deterioration of external sector indicators especially after the external shock in the form of global financial crisis in 2008-09 validates the rationality of selection the reference period.

After a descriptive and comparative analysis, a CVI covering all the indicators under three categories is developed to provide a uniform call on the issue of macroeconomic vulnerability of India's 
fiscal and external sector separately. To build CVI, each indicator $X_{t}^{i}$ under each category is transformed into a standardized $Z_{t}^{i}$ score, where $Z_{t}^{i}=\left(X_{t}^{i}-\mu\right) / \sigma, \mu$ and $\sigma$ are the mean and standard deviation (S.D) of the $i^{\text {th }}$ indicator over the years. The $Z$ score has a straightforward interpretation. A Z-score close to zero indicates that a particular indicator is close to the average. A high positive number implies a worse performance. For each of the three categories of indicators, unweighted average of the $Z$ score is calculated. To derive index for each categories, the $Z$ scores are transformed into a cumulative normal probability distribution, ranging from 0 to 10 with mean score of 5 . An Index value ranging from 5 towards 10 indicates high degree of vulnerability. Value below 5 indicates normality and points to less or absence of vulnerability. However, due to difference in period of analysis for three different categories, the combined unweighted average CVI has not been computed.

Table 1: Balance sheet indicators in India

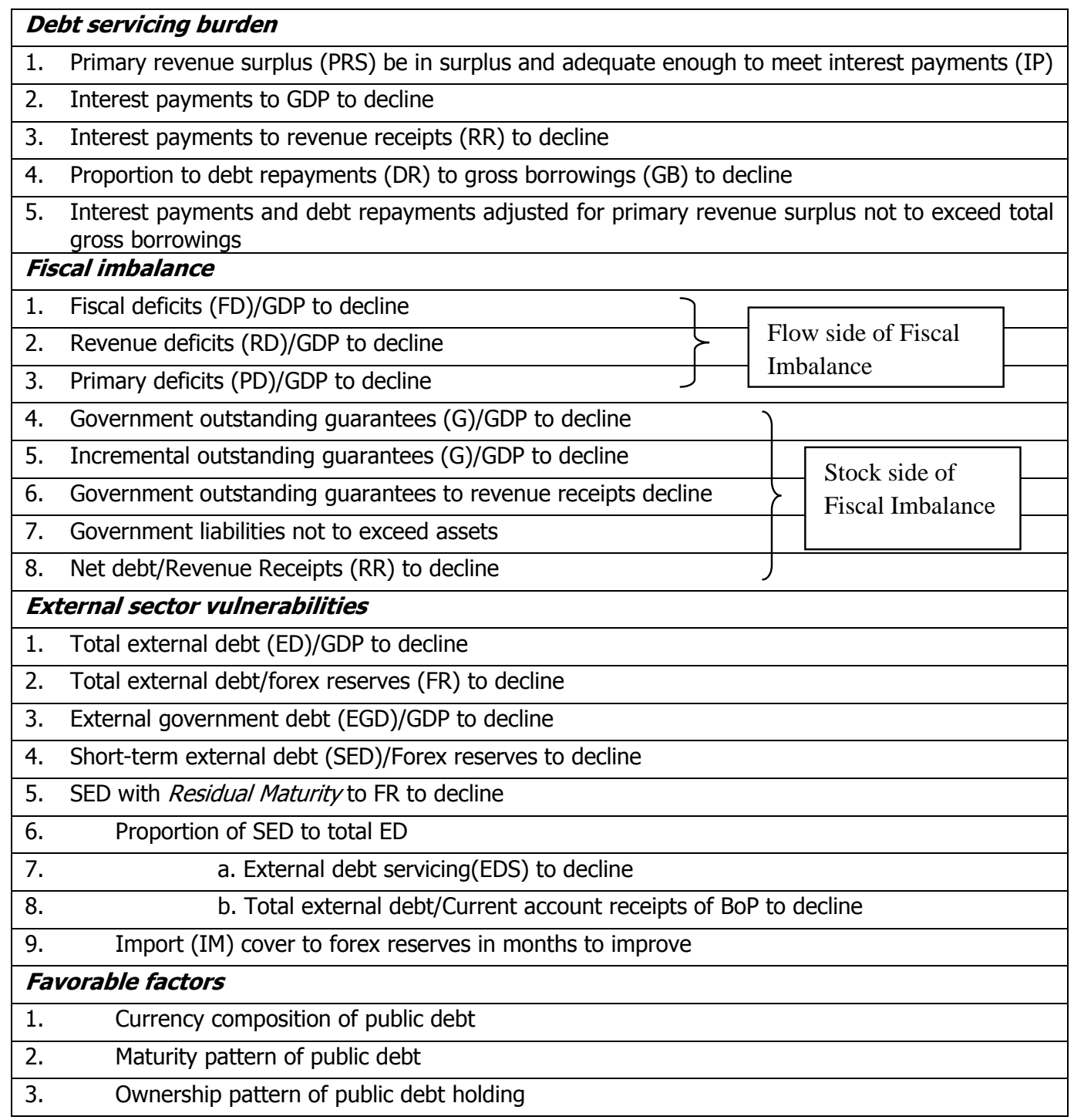

Source: Author, Roubini and Hemming (2004) and the IMF (2002, 2004, 2011b) 
Apart from focusing on vulnerability indicators, some other indictors like currency composition, maturity structure and ownership pattern of combined Union and State governments debt stocks have been used to identify the factors favorable to India's fiscal structure. These favorable factors are integral parts of a balanced approach to fiscal vulnerability. All the indicators used to assess balance sheet vulnerabilities are presented in Table 1.

\section{Variable Description and Data Sources}

Variable description and data sources for construction of balance sheets indicators in Indian context are given in Table 2.

Table 2: Variable description, measurement and data source

\begin{tabular}{|c|c|c|}
\hline Variables & Measurement and description & Data Source (s) \\
\hline $\begin{array}{l}\text { Primary Revenue } \\
\text { Surplus (PRS) }\end{array}$ & $\begin{array}{l}\text { Excess of revenue receipts (RR) over non- } \\
\text { interest revenue expenditures (NRE) defines } \\
\text { PRS. This is an important fiscal variable. If RR } \\
\text { short falls of NRE, it is primary revenue deficits } \\
\text { (PRD). }\end{array}$ & $\begin{array}{l}\text { Indian Public Finance } \\
\text { Statistics (from } 1999 \text { to } \\
\text { 2013), Government of } \\
\text { India. }\end{array}$ \\
\hline $\begin{array}{l}\text { Revenue Receipts } \\
\text { (RR) }\end{array}$ & $\begin{array}{l}\text { Sum of total tax and non-tax revenue receipts } \\
\text { of combined Union and State governments. }\end{array}$ & Same to above \\
\hline $\begin{array}{l}\text { Revenue Receipts } \\
\text { (RE) }\end{array}$ & $\begin{array}{l}\text { Sum of total developmental and non- } \\
\text { developmental revenue spending by combined } \\
\text { Union and State governments. }\end{array}$ & Same to above \\
\hline $\begin{array}{l}\text { Interest Payments } \\
\text { (IP) }\end{array}$ & $\begin{array}{l}\text { Interest paid on public debt stocks of combined } \\
\text { Union and State governments. }\end{array}$ & Same to above \\
\hline Debt Servicing & $\begin{array}{l}\text { Defined as the sum of interest payments and } \\
\text { repayments of debt of combined Union and } \\
\text { State governments. }\end{array}$ & Same to above \\
\hline Gross Borrowing (GB) & $\begin{array}{l}\text { Borrowing in cash by combined Union and State } \\
\text { Governments by issuing dated securities for } \\
\text { normal market borrowing and treasury bills. }\end{array}$ & Same to above \\
\hline Revenue Deficits (RD) & $\begin{array}{l}\text { It refers to the excess of revenue expenditure } \\
\text { over revenue receipts. }\end{array}$ & Same to above \\
\hline Fiscal Deficits (FD) & $\begin{array}{l}\text { It is the difference between the revenue } \\
\text { receipts plus non-debt capital receipts and the } \\
\text { total expenditure including loans and advances, } \\
\text { net of repayments. This indicates the total } \\
\text { borrowing requirements of Government from all } \\
\text { sources. }\end{array}$ & Same to above \\
\hline Primary Deficits (PD) & $\begin{array}{l}\text { It is measured by fiscal deficit less interest } \\
\text { payments. }\end{array}$ & Same to above \\
\hline Assets and Liabilities & $\begin{array}{l}\text { Assets include capital expenditures, loans and } \\
\text { advances, cash balance and investment, while } \\
\text { liabilities include internal debt, external debt, } \\
\text { small savings, reserve funds and other deposits } \\
\text { of combined Union and State governments. }\end{array}$ & $\begin{array}{l}\text { Combined Finance and } \\
\text { Revenue Account Statistics } \\
\text { of the Union and State } \\
\text { Governments in India (from } \\
2002 \text { to 2011). }\end{array}$ \\
\hline Contingent Liabilities & $\begin{array}{l}\text { Measured as the sum of outstanding } \\
\text { government guarantees extended from Union } \\
\text { and State government budgets. }\end{array}$ & $\begin{array}{l}\text { Annual Report of RBI (from } \\
2001 \text { to 2013), and State } \\
\text { Finance: Study of Budgets } \\
\text { (from } 2006 \text { to 2013). }\end{array}$ \\
\hline $\begin{array}{l}\text { Total External Debt } \\
\text { (ED) }\end{array}$ & $\begin{array}{l}\text { Sum of government and non-government debt } \\
\text { held in foreign currency. Non-government debt } \\
\text { includes debt held by financial sector, non- } \\
\text { financial private sector and public sector } \\
\text { enterprises. }\end{array}$ & RBI (2013). \\
\hline
\end{tabular}




\begin{tabular}{|l|l|l|}
\hline $\begin{array}{l}\text { Short-term External } \\
\text { Debt (SED) }\end{array}$ & $\begin{array}{l}\text { ED with an original maturity of up to one year is } \\
\text { classified as short-term debt. There two types } \\
\text { of SED with maturity of one year - SED with } \\
\text { original maturity and SED with residual } \\
\text { maturity. }\end{array}$ & RBI (2013). \\
\hline $\begin{array}{l}\text { Current Account } \\
\text { Receipts (CAR) }\end{array}$ & $\begin{array}{l}\text { It is defined as the sum of exports of goods and } \\
\text { services, transfer and income from abroad. }\end{array}$ & RBI (2013). \\
\hline Forex Reserves (FR) & $\begin{array}{l}\text { Sum of foreign currency assets, gold and } \\
\text { reserve tranche position. }\end{array}$ & RBI (2013). \\
\hline $\begin{array}{l}\text { External Debt } \\
\text { Servicing Ratio (EDS) }\end{array}$ & $\begin{array}{l}\text { Ratio of sum of payment of interest and } \\
\text { principal to CAR }\end{array}$ & RBI (2013). \\
\hline Import(IM) Coverage & $\begin{array}{l}\text { Measured as the number of months the existing } \\
\text { forex reserve can cover the import requirement. }\end{array}$ & RBI (2013). \\
\hline GDP & $\begin{array}{l}\text { Gross Domestic Production at current market } \\
\text { prices with 2004-05 base year }\end{array}$ & RBI (2013). \\
\hline
\end{tabular}

Source: Author's compilation

\section{Results}

\section{Indicators of debt servicing burden}

Table 3 describes the selected indicators of India's debt servicing burden to explain the existing fiscal structure and to identify the presence or absence of vulnerability. Satisfaction of symbolic representation and sign conditions as mentioned in the second column of Table 3 by different indicators helps to accomplish the above-mentioned objective.

Table 3: Debt Servicing Burden of Combined Union and State Governments (in percentage)

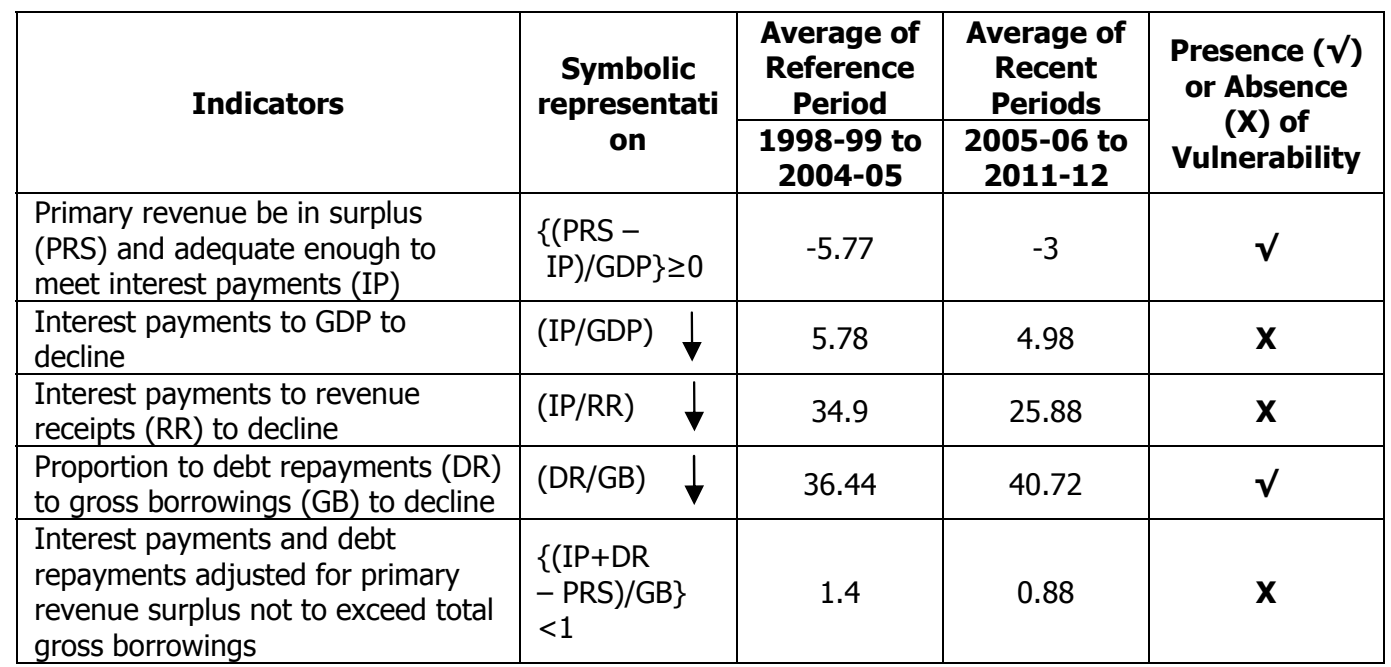

Source: Author's compilation based on various issues of Indian Public Finance Statistics (1999 to 2013) and the $R B I$ (2013).

When assessed in terms of debt service burden, the country's fiscal health gives room for serious concern. Generating adequate primary revenue surplus (PRS) to repay principle and interest amount is crucial. A strong and sustainable fiscal structure should at least generate enough PRS to meet the interest payments (IP). However, fiscal health assessment based on such a simple indicator does 
not fulfill the required sign condition and hence indicate the presence of vulnerability. The only improvement seen is the decline in its magnitude from - $5.77 \%$ during 1999 to 2005 to $-3 \%$ during 2006 to 2012. The improvement in fiscal health is $2.7 \%$ during the 2006 to 2012 . However, a serious concern exists, in that the revenue account has not been generating enough surpluses to cover at least the interest payments on existing debt stocks. Such inadequacy in the revenue account forces government to either draw surplus from capital account or borrow to meet the interest payment obligation. This constitutes an unhealthy practice in terms of fiscal sustainability. However, there has been a modest decline in IP/GDP from 5.78\% during 1999-2005 to 4.98\% during 2006-12. The debtservicing burden measured as a ratio of IP to revenue receipts (RR) reveals a better picture. While commenting on the vicious circle of growing IP to RR and its consequence on debt sustainability, the Eleventh Finance Commission (EFC) asked to limit the IP/RR ratio below 25\%. Decline in IP/RR ratio from $34.9 \%$ during $1999-2005$ to $25.9 \%$ during $2006-12$ clearly indicates a substantial decline in vulnerability of debt servicing burden.

The fiscal vulnerability assessment based on repayment obligation presents a worrisome picture as there has been an increase in the proportion of gross borrowings (GB) used for debt repayment (DR) from $36.44 \%$ during $1999-2005$ to $40.72 \%$ during $2006-12$. The ratio of IP and DR adjusted for PRS to GB is another important indicator of fiscal vulnerability. According to no-ponzi game (NPG) condition, a healthy fiscal policy does not allow the government to repay debt-servicing obligation from borrowings (Buiter and Patel, 1992). So long as the ratio of IP and DR adjusted for PRS to GB is either zero or less than one, the fiscal structure is considered strong. Decline in the ratio of IP and DR adjusted for PRS to GB from 1.44 during 1999-2005 to 0.88 during 2006-12 has been certainly an improvement, and signifies the absence of vulnerability.

From the above analysis, it is clear that the vulnerability as assessed in terms of most of the debt servicing burden indicators for combined Union and State governments has shown improvement in recent periods compared to the reference period. The decline in the summary indicator of IP and DR adjusted from PRS to GB to less than one (i.e. 0.88) undoubtedly signifies the absence of overall vulnerability in debt servicing burden. However, an increase in DR to GB ratio and inability to enough PRS to meet IP needs certainly indicate the weakness of fiscal structure.

\section{Indicators of fiscal imbalance}

The vulnerabilities in fiscal imbalances like high fiscal deficits (FD) to GDP ratio, revenue deficits (RD) to GDP and primary deficits (PD) to GDP ratios are widely used indicators to assess fiscal vulnerability in India. According to many researchers, the root cause of the major macroeconomic crisis in 1990-91 was the growing fiscal imbalance since early 1980s (Buiter and Patel, 1992; 2006). The transmission of the growing fiscal imbalance of 1980s to the external sector caused severe balance of payment crisis in early 1990s. Even today, such structural fiscal imbalance is a major cause of concern for fiscal sustainability. Even the FRBM Act (2003) for Union government and subsequently the FRL by various State governments have failed to achieve the stipulated deficit targets. Indeed, there has been a modest decline in FD/GDP, RD/GDP and PD/GDP, but instead of achieving zero RD or surplus in revenue account, the situation has worsened with RD rising to over $3 \%$ of GDP, and this is certainly a cause for 
concern. Similarly, the PD/GDP has important role to play in stabilizing debt/GDP for a given interest rate-GDP growth differentials. In Indian context, for bringing down the debt/GDP to below $60 \%$ mark from the current level of $70 \%$, generating primary surplus is essential. However, the continuation of PD (instead of any surplus) clearly indicates the upward pressure on debt/GDP, which severely undermine the favourable growth- interest rate differentials on debt/GDP and points weakness of the fiscal structure.

Table 4: Fiscal imbalance of combined Union and State governments (in percentage)

\begin{tabular}{|c|c|c|c|c|}
\hline \multirow[t]{2}{*}{ Indicators } & \multirow{2}{*}{$\begin{array}{l}\text { Symbolic } \\
\text { representation }\end{array}$} & $\begin{array}{c}\text { Average of } \\
\text { Reference } \\
\text { Period } \\
\end{array}$ & $\begin{array}{l}\text { Average of } \\
\text { Recent } \\
\text { Periods } \\
\end{array}$ & \multirow{2}{*}{$\begin{array}{c}\text { Presence }(\sqrt{ }) \\
\text { or absence }(X) \\
\text { of Vulnerability }\end{array}$} \\
\hline & & $\begin{array}{c}1998-99 \text { to } \\
2004-05\end{array}$ & $\begin{array}{c}2005-06 \text { to } \\
2011-12\end{array}$ & \\
\hline $\begin{array}{l}\text { Fiscal deficits (FD)/GDP to } \\
\text { decline and below the fiscal } \\
\text { rule target }\end{array}$ & $(F D / G D P) \& \leq 6 \downarrow$ & 8.59 & 6.87 & $\sqrt{ }$ \\
\hline $\begin{array}{l}\text { Revenue deficits (RD)/GDP } \\
\text { to decline and be in surplus } \\
\text { as per fiscal rule target }\end{array}$ & $(\mathrm{RD} / \mathrm{GDP}) \& \leq 0 \downarrow$ & 5.77 & 3 & $\sqrt{ }$ \\
\hline $\begin{array}{l}\text { Primary deficits (PD)/GDP } \\
\text { to decline }\end{array}$ & (PD/GDP) & 2.8 & 1.86 & $\sqrt{ }$ \\
\hline $\begin{array}{l}\text { Government outstanding } \\
\text { guarantees (G)/GDP to } \\
\text { decline }\end{array}$ & $(G / G D P)$ & 10.45 & 5.9 & $\mathbf{x}$ \\
\hline $\begin{array}{l}\text { Incremental G/GDP to be } \\
\text { below } 1 \% \text { of GDP }\end{array}$ & $\Delta(\mathrm{G} / \mathrm{GDP})<1 \%$ & 1.05 & $-0.05 \$$ & $\mathbf{x}$ \\
\hline $\begin{array}{l}\text { Government outstanding } \\
\text { guarantees to revenue } \\
\text { receipts decline }\end{array}$ & (G/RR) & 63.42 & 30.83 & $\mathbf{x}$ \\
\hline $\begin{array}{l}\text { Liabilities (L) not to } \\
\text { exceed assets }(A)\end{array}$ & $(\mathrm{L}-\mathrm{A}) / \mathrm{GDP} \leq 0$ & $43.26 *$ & 39.7 & $\mathbf{x}$ \\
\hline $\begin{array}{l}\text { Net debt/Revenue Receipts } \\
\text { (RR) to decline }\end{array}$ & $(\mathrm{L}-\mathrm{A}) / \mathrm{RR}$ & 229.08* & 180.24\# & $\mathbf{x}$ \\
\hline
\end{tabular}

Source: Author's compilation based on various issues of Annual Report of RBI (from 2001 to 2013), and State Finance: Study of Budgets (from 2006 to 2013), Indian Public Finance Statistics (from 1999 to2013) and the RBI (2013).

Note: \$ indicates average from 2005-06 to2009-10, *indicates average from 2001-02 to 2004-05 and \# indicates average from 2005-06 to 2010-11 due to constraint on data availability.

Focusing on the other crucial fiscal imbalance parameters like contingent liabilities and net debt defined as the difference between liabilities and assets of government, is equally important. Such stock imbalances generally receive less attention from policy makers and researchers while analyzing fiscal vulnerability. In order to assess the overall fiscal vulnerability, the fiscal risk involved in the contingent liabilities and growing assets-liability mismatch should be factored in and analyzed in detail.

In India, the Union and State government together, in addition to its explicit debt, have piled up a significant quantum of implicit/contingent liabilities. Contingent liabilities are obligations if some unforeseen events occur. Contingent liabilities are of two types - explicit contingent liabilities (ECLs) and implicit contingent liabilities (ICLs). The ECLs are specific government obligations defined by law or 
contract. The government is legally compelled to settle such obligations when dues arise. The ICLs are not legally binding, but represents a moral obligation based on public expectations and political pressure. Such liabilities are hidden debt and a source of hidden threat to fiscal vulnerability. Apart from contingent liabilities, the growing incidence of off-budget borrowing by both Union and State governments through special purpose vehicles (SPVs) represent another source of fiscal risk. According to RBI report (2005), such liabilities, in principle, are contingent liabilities. However, in practice, since the SPVs do not have independent source of revenue generation, such liabilities are actual liabilities of respective governments. Thus, fiscal adjustment that targets deficit and debt reduction does not necessarily prevent fiscal crisis. Due to lack of transparency in the management of fiscal policy, generally, information on such off budget and contingent liabilities remains sketchy. Due to data constraint on contingent and off- budget liabilities of combined Union and State governments, Table 4 provides the information on outstanding government guarantees as shown in the various budget documents of respective governments. The outstanding guarantees (G) as a percentage of GDP was substantially higher during 1999-2005 and exceeded 10\% during this period. The FRBM Act, 2003 put a cap on incremental annual outstanding guarantees at $0.5 \%$ of GDP for Central government. However, uniformity lacks across State governments in extending the outstanding guarantees. However, after the enforcement of FRBM Act for Union government and FRL for State government, which brought better transparency and fixed statutory limit on outstanding guarantees extended by respective governments, the G/GDP ratio came down substantially from $10.5 \%$ during $1999-2005$ to $5.9 \%$ during $2006-12$. For a better assessment of fiscal risk arising out of such guarantees, one needs to look at the G/RR ratio, which indicates the quantum of RR needed to replace guarantees. The G/RR ratio during 1999-2005 remained substantially higher at $60 \%$. This implies that instead of guarantees, direct budgetary support would have consumed a large chunk of resources. Thus, such high magnitude of G/RR indicates a great deal of hidden fiscal risk in India's fiscal structure. However, substantial decline in G/RR ratio to $30.83 \%$ during 2006-12 is certainly an improvement, and signifies the effectiveness of rule based fiscal management that seeks to improve budgetary transparency and contain contingent liabilities in order to reduce hidden fiscal risk.

The other indicator i.e. net debt/GDP or net liabilities/GDP is important while applying balance sheet approach to identify fiscal vulnerability. There has been no mention of net debt/GDP in most countries' fiscal deficit or public debt/GDP targets fixed for sustainable public finance. The sole exception is the UK government's target of net debt/GDP fixed at below $40 \%$ as an indicator of sustainable fiscal policy (HM Treasury, 2008). The theoretical judgment for such indicators arises from the fact that government expenditures, even if financed by public debt, not only create liabilities, but also create assets that provide future revenue generation (Buiter and Patel, 2010). Due to lack of adequate information on the assets and liabilities position of combined Union and State governments prior to 2002, the present analysis is restricted to data for 9 years i.e. from 2001-02 to 2010-11. In India, there is no target of net debt/GDP to determine the sustainable path of public debt. However, it can be seen from Table 4 that the net debt/GDP hovers around 40\% for the period 2002 to 2012 . Thus, though the present gross debt/GDP is higher than different Finance Commissions' targets, net debt/GDP or net debt/RR ratio do not pose serious concern from the angle of fiscal vulnerability analysis. Similarly, 
there has been a large decline in net debt/RR ratio from $229 \%$ during $2002-05$ to $180 \%$ during 200611. However, the ideal ratio should not exceed $100 \%$ mark. A large decline in it in recent years certainly indicates an improvement in vulnerability.

\section{External sector indicators}

While deliberating on external sector vulnerabilities, two types of inter-related solvency risks, namely, the risk of country default and government default on external payment obligations are mentionable. A country's default arises due to an excessive accumulation of external debt relative to its ability to service that debt. Similarly, government default on external obligation arises if excessive budget deficits result in accumulating large external public debt relative to the capacity to service. The country default risk may arise due to excess leverage of private sector to external borrowing, and such default can happen even if the indicators of public finance of concerned country are strong. However, any type of external default leads to currency crisis in a country and adversely affects its public finance, causing bottlenecks in meeting external repayment obligations and severe macroeconomic crisis.

Table 5: External sector indicators (in percentage)

\begin{tabular}{|c|c|c|c|c|}
\hline Indicators & $\begin{array}{l}\text { Symbolic } \\
\text { representation }\end{array}$ & $\begin{array}{c}\text { Average of } \\
\text { Reference } \\
\text { Period }\end{array}$ & $\begin{array}{l}\text { Average of } \\
\text { Recent } \\
\text { Periods } \\
2008-09 \text { to }\end{array}$ & $\begin{array}{c}\text { Presence }(\sqrt{ }) \\
\text { or Absence } \\
(X) \text { of }\end{array}$ \\
\hline $\begin{array}{l}\text { Total external debt } \\
\text { (ED)/GDP to decline }\end{array}$ & $\begin{array}{ll}\text { (ED/GDP) } & \downarrow\end{array}$ & 32.67 & 18.9 & $\mathbf{X}$ \\
\hline $\begin{array}{l}\text { External government } \\
\text { debt (EGD)/GDP to decline }\end{array}$ & (EGD/GDP) & 13.79 & 3.93 & $\mathbf{X}$ \\
\hline $\begin{array}{l}\text { Total ED to current account } \\
\text { receipts (CAR) to decline }\end{array}$ & $(E D / C A R)$ & 360.04 & 69.73 & $\mathbf{X}$ \\
\hline $\begin{array}{l}\text { Total external debt/forex } \\
\text { reserves (FR) to decline }\end{array}$ & $(E D / F R)$ & 1244.1 & 100.01 & $\mathbf{X}$ \\
\hline $\begin{array}{l}\text { Short-term external debt (SED)/ } \\
\text { Forex reserves to decline }\end{array}$ & (SED/FR) & 116.75 & 20.95 & $\mathbf{X}$ \\
\hline $\begin{array}{l}\text { SED with Residual } \\
\text { Maturity (RM)/FR to decline }\end{array}$ & $\begin{array}{l}\{\mathrm{SED}(\mathrm{RM}) / \\
\text { FR }\}\end{array}$ & $233.58^{*}$ & 27.5 & $\mathbf{X}$ \\
\hline Proportion of SED to total ED & $(\mathrm{SED} / E D)$ & 9.23 & 20.81 & $\sqrt{ }$ \\
\hline $\begin{array}{l}\text { External debt servicing(EDS) } \\
\text { to decline }\end{array}$ & $(E D S)$ & 32.75 & 5.15 & $\mathbf{X}$ \\
\hline $\begin{array}{l}\text { Import (IM) cover to forex } \\
\text { reserves in months to improve }\end{array}$ & (IM/FR) & 3.9 & 9.4 & $\mathbf{X}$ \\
\hline
\end{tabular}

Source: Author's compilation based on various issues of Indian Public Finance Statistics (1999 to 2013) and the RBI (2013) and various issues on India's External Debt: A Status Report (from 2001 to 2012).

* indicates the figure corresponds to 1991only due to data availability constraint.

As can be seen form Table 5, the total external debt (ED) to GDP ratio and external government debt (EGD) to GDP ratio declined substantially in recent years i.e. 2009-12. Such secular decline in ED/GDP and EGD/GDP has undoubtedly reduced external vulnerability largely. Besides, there has been a steady decline in ED to current account receipts (CAR) ratio from 360\% during 1990-92 to 
69.73\% during 2009-12. Similarly, an unprecedented decline in ED to forex reserve (FR) ratio from $1244 \%$ during $1990-92$ to $100 \%$ during $2009-12$ marks a remarkable improvement. Such improvements have largely reduced the possibility of India's sovereign external default.

The analysis of debt service payments and debt service ratio also assumes a central role in external debt analysis. The EDS serves as an important indicator of external vulnerability and a larger outgo on account of EDS strains a country's forex reserves and exposes the nation to external shocks. The country's external debt servicing (EDS) ratio, defined as the sum of interest and principal repayments to total current account receipts of balance of payments, has shown a steady decline from $32.75 \%$ during $1990-92$ to $5.2 \%$ during $2009-12$. Similarly, the improvement in import cover (IM) to the forex reserves has largely reduced the vulnerability to external shocks. Thus, the remarkable decline in ED/GDP, EGD/GDP, ED/CAR, ED/FR, EDS and improvement in IM/FR ratio has kept the possibility of external payment crisis at bay.

As can be seen from Table 5, what is more worrisome is the unfavorable ratio of short-term external debt (SED) to ED. The proportion of SED to ED has registered phenomenal increase from $9.23 \%$ during $1990-92$ to $20.81 \%$ during $2008-12$. However, a phenomenal decline in SED with residual maturity to FR ratio from $233.58 \%$ in 1991 to $27.5 \%$ during $2008-12$ has largely reduced the financing risk and repayment obligations of external debt. Thus, if one needs to summarize about the immediate financing needs for external payment obligations, a phenomenal decline in SED to forex ratio to $27 \%$ during 2009-12 undoubtedly nullifies the threat of external repayment risk and signifies the overall absence of external vulnerability.

Table 6: Composite Vulnerability Index

\begin{tabular}{|c|c|c|c|c|c|c|c|}
\hline \multicolumn{2}{|c|}{$\begin{array}{l}\text { Score of Debt } \\
\text { Servicing Burden }\end{array}$} & \multicolumn{2}{|c|}{$\begin{array}{l}\text { Score of Flow Fiscal } \\
\text { Imbalance }\end{array}$} & \multicolumn{2}{|c|}{$\begin{array}{c}\text { Score of Flow \& } \\
\text { Stock sides } \\
\text { Fiscal Imbalance }\end{array}$} & \multicolumn{2}{|c|}{$\begin{array}{l}\text { Score of External } \\
\text { Indicators }\end{array}$} \\
\hline $\begin{array}{c}1998-99 \\
\text { to } \\
2004-05\end{array}$ & $\begin{array}{c}2005-06 \\
\text { to } \\
2011-12\end{array}$ & $\begin{array}{c}1998-99 \\
\text { to } \\
2004-05\end{array}$ & $\begin{array}{c}2005-06 \\
\text { to } \\
2011-12\end{array}$ & $\begin{array}{c}2001-02 \\
\text { to } \\
2004-05\end{array}$ & $\begin{array}{c}2005-06 \\
\text { to } \\
2009-10\end{array}$ & 1990-92 & $\begin{array}{c}2009 \\
\text { to } \\
2012\end{array}$ \\
\hline 5.6 & 4.4 & 5.49 & 4.5 & 5.7 & 4.44 & 5.8 & 4.5 \\
\hline
\end{tabular}

Source: Author's compilation.

After a descriptive and comparative analysis of different indicators under three categories, it is time to take look at the summary of CVI scores, as provided in Table 6. The decline in the score of debt servicing burden from 5.6 during 1999-2005 and to 4.4 during 2006-12 is in line with the results of the descriptive and comparative analysis. Similar is the case of flow side and stock side fiscal imbalance during the same period. The most remarkable improvement was found in external sector indicators. There has been a marked decline in external sector score from 5.8 during 1990-92 to 4.5 during 200912. Even though there has been deterioration in some of the external sector indicators, overall external indicators have been providing a great deal of comfort to India in recent periods. Further, the decline of the overall score below 5 in recent years is indicative of the very low degree of overall fiscal and external vulnerability of the country. From the above analysis, it is clear that the overall trend of debt servicing burden, fiscal imbalance and external sector indicators obtained by descriptive and comparative analysis is largely in line with the CVI analysis. 


\section{Factors Favorable to India}

In the above section, we analyzed India's balance sheet vulnerabilities pertaining to the combined Union and State governments' debt servicing burden, fiscal imbalance and country's external vulnerabilities. What follows is the analysis of certain distinctly favorable factors that largely help to reduce and mitigate balance sheet vulnerabilities.

Firstly, a look at the currency composition, as provided in Table 7, of the combined Union and State governments makes it clear that the proportion of external debt to total combined debt has drastically reduced from around 15\% during 1998-99 to around 5.5\% during 2009-12. The steady fall in government external debt/GDP during the same period also suggests that Indian policy makers have been largely successful in moderating the burden of foreign currency liabilities. The reduction in external government debt/GDP ratio or the share of foreign currency debt to total combined debt, without noticeable reduction in overall debt/GDP, implies an equivalent proportionate increase in debt burden in local currency. Such a transitional shift indeed has largely helped Indian sovereign to curtail the vulnerabilities to external shock. However, Buiter and Patel (2006) have criticized such transition, as swapping the interest of pressure creating external creditors to hapless future generations of Indian citizen. As currency composition is an important indicator of fiscal vulnerability, financing budget deficits in domestic currency largely helped Indian government to reduce the solvency risk.

Table 7: Composition of Combined Union and State Governments Public Debt (1991 to 2012)

\begin{tabular}{|l|c|c|c|c|}
\hline Year & $\begin{array}{c}\text { Proportion of External } \\
\text { Debt to Total Debt }\end{array}$ & $\begin{array}{c}\text { Proportion of Internal } \\
\text { Debt to Total Debt }\end{array}$ & $\begin{array}{c}\text { External Debt } \\
\text { to GDP Ratio }\end{array}$ & $\begin{array}{c}\text { Internal Debt } \\
\text { to GDP Ratio }\end{array}$ \\
\hline $1998-99$ & 14.70 & 85.30 & 9.87 & 57.24 \\
\hline $1999-00$ & 13.10 & 86.90 & 9.23 & 61.24 \\
\hline $2000-01$ & 11.84 & 88.16 & 8.73 & 64.94 \\
\hline $2001-02$ & 10.76 & 89.24 & 8.47 & 70.32 \\
\hline $2002-03$ & 9.33 & 90.67 & 7.73 & 75.13 \\
\hline $2003-04$ & 7.79 & 92.21 & 6.48 & 76.75 \\
\hline $2004-05$ & 7.18 & 92.82 & 5.90 & 76.24 \\
\hline $2005-06$ & 6.79 & 93.21 & 5.25 & 73.82 \\
\hline $2006-07$ & 6.33 & 93.67 & 4.68 & 69.98 \\
\hline $2007-08$ & 6.00 & 94.00 & 4.21 & 67.23 \\
\hline $2008-09$ & 6.78 & 93.22 & 4.69 & 67.52 \\
\hline $2009-10$ & 5.56 & 94.44 & 3.85 & 66.78 \\
\hline $2010-11$ & 5.46 & 94.54 & 3.58 & 61.95 \\
\hline $2011-12$ & 5.49 & 94.51 & 3.60 & 61.92 \\
\hline
\end{tabular}

Source: Author's compilation based on the RBI Hand (2013)

Secondly, the higher maturity of debt issuance and outstanding stock (see Table 8) suggests that debt management authority in India has successfully elongated the maturity structure of debt to reduce the refinancing risk of debt and deficits. The elongation of maturity is another dimension to debt vulnerability. Shorter the maturity of debt, larger is risk of refinancing and solvency. Further, a look at 
the share of short-term debt of Union government, State governments and combined Union and State governments taken together, reveals that roughly around $10 \%$ of Union government debt, $4 \%$ of State government debt and $8 \%$ of combined government debt are short-term debt (see detailed breakup in Table 8).

Thirdly, apart from currency composition and maturity structure of debt, the ownership pattern of debt adds another dimension to debt related vulnerability. As can be seen form Table 9, a large share of the combined Union and State governments securities is held by the Reserve Bank of India, Scheduled Commercial Banks (SCBs) and other long-term investors like insurance companies, provident funds and financial institutions. In India, historically the SCBs have been the predominant investors in government securities due to the requirement of SCBs to conform to the high statutory liquidity ratio (SLR) prescribed by the Reserve Bank of India from time to time. The RBI holds a part of government securities as part of their monetary policy. In addition, long-term investors such as insurance companies, provident funds and financial institutions are obliged to conform to several norms and statutory requirements. Consequently, a large chunk of government securities remains in the hands of such captive inventors in India. Since government has majority ownership in such captive investors group, refinancing risk of debt or deficits is very limited. This consequently has reduced the possibility of a run by domestic or foreign investors on government debt to a minimum.

Table 8: Maturity Pattern of Combined Union and State Government Debt

\begin{tabular}{|c|c|c|c|c|c|}
\hline Years & $\begin{array}{c}\text { Weighted } \\
\text { Average } \\
\text { Maturity } \\
\text { during Issuing } \\
\text { Years }\end{array}$ & $\begin{array}{c}\text { Weighted } \\
\text { Average } \\
\text { Maturity of } \\
\text { Outstanding } \\
\text { Debt Stock }\end{array}$ & $\begin{array}{c}\text { State } \\
\text { Governments' } \\
\text { Short-term } \\
\text { Debt / State } \\
\text { Governments' } \\
\text { Total Debt }\end{array}$ & $\begin{array}{c}\text { Central } \\
\text { Government } \\
\text { Short-term } \\
\text { Debt / Central } \\
\text { Government } \\
\text { Total debt }\end{array}$ & $\begin{array}{c}\text { Combined } \\
\text { Short-term } \\
\text { Debt / } \\
\text { Combined } \\
\text { Debt }\end{array}$ \\
\hline $2000-01$ & - & - & 4.1 & 12.36 & 11.48 \\
\hline $2001-02$ & - & - & 4.48 & 12.09 & 11.4 \\
\hline $2002-03$ & - & - & 3.94 & 9.52 & 9.15 \\
\hline $2003-04$ & 14.94 & 9.78 & 4.21 & 4.37 & 5.07 \\
\hline $2004-05$ & 14.13 & 9.63 & 3.56 & 4.32 & 4.8 \\
\hline $2005-06$ & 16.9 & 9.92 & 3.77 & 5.87 & 6.22 \\
\hline $2006-07$ & 14.72 & 9.97 & 3.24 & 6.31 & 6.44 \\
\hline $2007-08$ & 14.9 & 10.59 & 3.37 & 6.64 & 6.73 \\
\hline $2008-09$ & 13.81 & 10.45 & 4.46 & 9.22 & 9.1 \\
\hline $2009-10$ & 11.16 & 9.67 & 3.98 & 9.71 & 9.18 \\
\hline $2010-11$ & 11.62 & 9.64 & 4.14 & 8.02 & 7.86 \\
\hline $2011-12$ & 12.66 & 9.6 & 4.45 & 10.13 & 9.54 \\
\hline $2012-13$ & 13.5 & 9.66 & - & - & - \\
\hline Average & $\mathbf{1 3 . 8 3}$ & $\mathbf{9 . 8 9}$ & $\mathbf{3 . 9 8}$ & $\mathbf{8 . 2 1}$ & $\mathbf{8 . 0 8}$ \\
\hline
\end{tabular}

Source: Author's compilation based on Government Debt: Status Paper (from 2010 to 2013) and the RBI (2013) 
Table 9: Ownership Pattern of Combined Union and State Government Securities

(1991 to 2012)

\begin{tabular}{|c|c|c|c|}
\hline Year & RBI Share & $\begin{array}{c}\text { Scheduled Commercial } \\
\text { Bank's Share }\end{array}$ & $\begin{array}{c}\text { Share of RBI + Scheduled Commercial } \\
\text { Bank + Provident Fund + Financial } \\
\text { Institutes + Insurance Companies }\end{array}$ \\
\hline 1998 & 10.66 & 58.90 & 69.56 \\
\hline 1999 & 9.10 & 59.50 & 68.60 \\
\hline 2000 & 6.98 & 60.86 & 67.84 \\
\hline 2001 & 7.72 & 60.95 & 68.67 \\
\hline 2002 & 6.39 & 60.62 & 67.01 \\
\hline 2003 & 6.55 & 58.56 & 65.11 \\
\hline 2004 & 4.09 & 56.12 & 60.20 \\
\hline 2005 & 5.19 & 52.38 & 57.57 \\
\hline 2006 & 4.95 & 46.46 & 51.41 \\
\hline 2007 & 7.48 & 46.93 & 54.41 \\
\hline 2008 & 6.57 & 50.99 & 82.29 \\
\hline 2009 & 7.07 & 50.39 & 80.45 \\
\hline 2010 & 8.90 & 51.99 & 85.52 \\
\hline 2011 & 8.57 & 51.39 & 87.09 \\
\hline 2012 & 10.37 & 53.81 & 89.41 \\
\hline
\end{tabular}

Source: Author's compilation based on the RBI (2013)

\section{Conclusion and Implications}

The paper has discussed and analyzed the different aspects of measuring balance sheet vulnerabilities in India's fiscal structure and external sector. Except the proportion of gross borrowing to debt repayments, all other debt servicing and fiscal imbalance indicators have improved substantially in recent years. However, inherent weaknesses like failure to generate adequate primary revenue surplus as also to achieve fiscal rule targets persist in our fiscal structure. In case of external vulnerability analysis, there has been a remarkable improvement in most of the indicators, except the increase in net external indebtedness, which is attributed to the high current account deficits of recent years. The favorable maturity pattern, currency composition and ownership pattern of combined Union and State government debt have largely helped to reduce the refinancing risk of debt and deficits and limit the possibility of a run by domestic or external investors on government debt. If the inability to smooth financeability of debt, deficits and external sector financing needs is perceived as fiscal and external sector vulnerability, it can be said that India does not face risk of such threat at present and hence signifies the absence of any overall macroeconomic vulnerability than generally perceived.

The findings and conclusions of the paper are largely at variance with the study by Roubini and Hemming (2004) mainly because the scope of the present study is limited to a broad based detailed indicator wise analysis under debt servicing burden, fiscal imbalance of flow and stocks side and external sector. Especially, when we look at the net debt/GDP ratio or the incremental outstanding guarantees to GDP ratio of combined Union and State governments, the findings like unsustainable public debt by them get largely negated. Similarly, the assessment of debt-servicing burden based on 
different indicators rather than on focusing on interest payments to revenue receipts ratio, largely nullifies the vulnerability. Rule based fiscal management initiated since 2004 in the form of FRBM at

Centre and FRL at State level too has helped to improve most of the indicators substantially and to lessen India's fiscal sector vulnerability. The external sector indicators, except the ratio of short-term external debt to total external debt, have shown remarkable improvements in recent years and is now nowhere close to 1990-91 level as averred by Roubini and Hemming.

However, the findings do not necessarily imply the complete absence of vulnerability. In fact, the sustained increase in India's net external indebtedness along with CAD/GDP, persistent downward pressure on rupee, quantum jump in short-term external debt and decline in overall growth and investment prospects point to the presence of some macroeconomic vulnerability. Thus, the major implication of this study's findings is that while the overall fiscal and external sector vulnerability is far below than what is generally perceived, it is nevertheless high time that we took appropriate policy actions to limit the CAD/GDP within manageable limits, restrict shorter maturity external commercial borrowings and revive investment and growth prospects.

\section{References}

Bachellerie, A and B Couillault (2005). Public Debt Sustainability and Crises in Emerging Market Countries: A Presentation of the Concepts and Diagnostic Tools. Financial Stability Review, Banque de France, 6: 63-80.

Buiter, W H and U R Patel (1992). Debt, Deficits and Inflation: An Application to the Public Finances of India. Journal of Public Economics, 4: 171-205.

- (2006). Excessive Budget Deficits, A Government Abused Financial System and Fiscal Rules. India Policy Forum. 2 (1): 1- 54.

- (2010). Fiscal Rules in India: Are They Effective? NBER Working Paper \# 15934.

ECB (2007). Assessing Fiscal Soundness: Theory and Practice. European Central Bank (ECB) Occasional Paper Series \# 56, Germany.

- (2011). Ensuring Fiscal Sustainability in the Euro Area. Monthly Bulletin, European Central $\operatorname{Bank}(E C B)$.

Eichengreen, B, R Hausmann and U Panizza (2002). Original Sin: The Pain, The Mystery and the Road to Redemption. In B Eichengreen and R Hausmann (eds), Currency and Maturity Matchmaking: Achieving Redemption From Original Sin. Chicago: University of Chicago Press.

(2003). Currency Mismatches, Debt Intolerance and Original Sin: Why they are not the same and why it matters. NBER Working Paper \# 10036.

HM Treasury (2008). Long-term Public Finance Report: An analysis of Fiscal Sustainability. United Kingdom (UK): HM Treasury.

IMF (2002). A Balance Sheet Approach to Financial Crisis. IMF Working Paper \# WP/02/210.

- (2004). Debt-Related Vulnerabilities and Financial Crises - An Application of the Balance Sheet Approach to Emerging Market Countries. Policy Development and Review Department, IMF. 
(2008). A Risk-Based Debt Sustainability Framework: Incorporating Balance Sheets and Uncertainty. IMF Working Paper \# WP/08/40, Fiscal Affairs Department.

- (2011a). Modernizing the Framework for Fiscal Policy and Public Debt Sustainability Analysis. Prepared by the Fiscal Affairs Department and the Strategy, Policy and Review Department. - (2011b). Measuring Fiscal Vulnerability and Fiscal Stress: A Proposed Set of Indicators. IMF Working Paper \# WP/11/94, Fiscal Affairs Department.

(2012), A Toolkit to Assessing Fiscal Vulnerabilities and Risks in Advanced Economies. IMF Working Paper \# WP/12/11, Fiscal Affairs Department.

Government of India (1999-2013). Indian Public Finance Statistics. Various Issues from 1999 to 2013, Ministry of Finance, Department of Economic Affairs, New Delhi.

- (2001-2012). India's External Debt: A Status Report. Various Issues from 2001 to 2012, Ministry of Finance, Department of Economic Affairs, New Delhi.

- (2002-2011). Combined Finance and Revenue Account Statistics of the Union and State Governments in India. Various Issues from 2002 to 2011, New Delhi.

- (2000). The Report of the Eleventh Finance Commission. New Delhi: Finance Commission. - (2010-2013). Government Debt: Status and Road Ahead. Various Issues from 2010 to 2013, New Delhi: Ministry of Finance

Poeck, A V and M Wijffelaars (2012). Banking Crises and Sovereign Debt Build-up: Implications for Debt Sustainability. Paper presented for the $30^{\text {th }}$ SUERF Colloquium States, Banks, and the Financing of the Economy, Switzerland.

Reserve Bank of India (2001-2013). Annual Report of RBI. Various Issues from 2001 to 2013. RBI: Mumbai.

(2006-2013). State Finance: Study of Budgets. Various Issues from 2006 to 2013. RBI: Mumbai.

- (2005). Report of the Working Group on Compilation of State Government Liabilities. RBI: Mumbai.

(2013). Handbook of Statistics on the Indian Economy 2012-13. RBI: Mumbai.

Reinhart, M C, K S Rogoff and M A Savastano (2003). Debt Intolerance. Brookings Papers on Economic Activity.

Reinhart, M C and K S Rogoff (2008). The Forgotten History of Domestic Debt. NBER Working Paper No. 13946.

Roubini, N and R Hemming (2004). A Balance Sheet Crisis in India? Paper presented at the IMF/NIPFP Conference on Fiscal Policy in India, New Delhi.

Wyplosz, C (2007). Debt Sustainability Assessment: The IMF Approach and Alternatives. HEI Working Paper \# 03/2007, Graduate Institute of International Studies, Geneva.

Yeyati, E L, and F Sturzenegger (2007). A Balance-Sheet Approach to Fiscal Sustainability. CID Working Paper \# 150, Harvard University. 